of any two is altered to a known degree, the whole equilibrium involving the other six could be calculated. These relations he expressed in the form of nomograms in his book "Blood" which appeared in 1928. As the concentrations of the above factors in the blood are largely governed by its surroundings, Henderson's mind was much concerned with the general topic of 'environment', to which subject he made a contribution of great importance in his book "The Fitness of the Environment" (1913). Lastly, Henderson himself appreciated that the blood does not spend long enough in any one set of surroundings for the complete establishment of the equilibria appropriate to them; it is upon this subject that he is giving a short course of lectures on October 16 , 17 and 18 at University College, London, and on October 19, 23 and 24 in the Physiological Laboratory, Cambridge.

\section{Tribute to Prof. E. G. Coker}

THE retirement of Prof. E. G. Coker from the Kennedy chair of civil and mechanical engineering in University College, London, was the subject of a couple of paragraphs in the News and Views columns of Nature of August 11. Opportunity was then taken to refer to a few outstanding points in Prof. Coker's career and work, particularly his researches on the use of polarised light in determining the distribution of stress in machines and structures. On October 11, a complimentary dinner was given to Prof. Coker at University College, London, and he was presented with a cine-camera and a cheque by past and present colleagues and students. Lord Rutherford, who presided over a large assembly representing various departments of university teaching and research, recalled the days when Prof. Coker was associate professor of civil engineering in McGill University, Montreal, and he himself was Macdonald professor of physies in the same University. Since then Prof. Coker's pioneer work has been recognised by his election as a fellow of the Royal Society, and by the use of his results in solving many scientific and engineering problems. Prof. L. N. G. Filon, who collaborated with Prof. Coker in the production of the exhaustive treatise on photo-elasticity, published in 1932, added his tribute to that of Lord Rutherford. In his reply, Prof. Coker said that the council of the College has permitted him to take away much of the apparatus which he used in his researches, and that he proposes to continue his work in a laboratory which he has constructed near his home.

\section{Thomas Henry, F.R.S. (1734-1816)}

Thomas Henry, the senior member of that family of chemists whose exploits won for them no mean place in the history of the science, was born at Wrexham on October 26, 1734. On leaving the local grammar school, he was apprenticed to an apothecary at Wrexham, but completed his initial training at Knutsford, and afterwards became chief assistant to a Mr. Malbon at Oxford. In 1759 he returned to Knutsford, and in 1764 established himself as an apothecary in Manchester, where he continued in practice for almost half a century. Notwithstanding his extensive practice, he was an ardent experimentalist and ambitious to extend the boundaries of chemical science. His numerous publications testify to his wide interests and his unremitting labour, "An Improved Method of Preparing Magnesia Alba", "Experiments on the Influence of Fixed Air on Vegetation", "Experiments on Ferments and Fer. mentation", and "The Nature of Wool, Silk, and Cotton as Objects of the Art of Dyeing" being a selection of the papers he communicated to learned societies. To-day his name is, perhaps, chiefly associated with "Henry's Calcined Magnesia", a preparation patented by him which is still on the market. Henry was elected a fellow of the Royal Society in 1775 on the recommendation of his friends Sir John Pringle, Joseph Priestley, and Benjamin Franklin. On the foundation of the Manchester Literary and Philosophical Society in 1781 , he was elected one of the secretaries, and was the president from 1807 until his death in 1816. He was a keen educationist, and gave lectures in Manchester on chemistry and on bleaching, dyeing, and calico printing. Henry was essentially a practical man. He saw the need for the application of chemical knowledge to the arts and crafts, and in attempting to meet that need did much towards paving the way for the union of pure and applied chemistry.

\section{Chemistry in Industry}

BRITISH chemical industry has in recent years been the subject of political discussion, of Governmental action, and of no little anxiety among those who realise the effect which duties, quotas, restrictions, and the like may have for better or for worse on a great national enterprise which has scarcely reached adolescence. In a world of such complex economics, the necessity of an organisation whereby exchange of views and corporate action are facilitated becomes at once apparent, and it is therefore not surprising that the Association of British Chemical Manufacturers finds its activities and its responsibilities increasing year by year. In moving the adoption of the Council's report at the annual general meeting of the Association, held on October 11, the chairman, Mr. F. H. Carr, referred at some length to its activities, its extending influence, and its increasing membership. There has been an unusually heavy loss by death of leaders in the industry; reference was specially made to the late Sir Max Muspratt, a founder and a wise counsellor who played a great part in the development of British chemical industry and contributed in no small degree to the strength and reputation of the Association. By the service of Sir Max Muspratt and many men of like character and attainments, and by the devotion of the staff, the Association to-day finds itself able to protect the interests of British chemical manufacturers to a degree undreamed of when it was first formed. Its membership roll now includes no fewer than one hundred and eleven firms, and other applications are pending. 